\title{
Inflammatory Response to Oxygen and Endotoxin in Newborn Rat Lung Ventilated With Low Tidal Volume
}

\author{
ANDREAS A. KROON, JINXIA WANG, ZHEN HUANG, LEI CAO, MACIEJ KULISZEWSKI, AND MARTIN POST
}

\begin{abstract}
Lung Biology Research, Physiology and Experimental Medicine Program [A.A.K., J.W., Z.H., L.C., M.K., M.P.], Hospital for Sick Children Research Institute, Toronto, Ontario M5G 1X8, Canada; Departments of Pediatrics and Physiology [M.P.], University of Toronto, Toronto, Canada M5S 1A8; Department of Pediatrics [A.A.K.], Erasmus MC-Sophia, Rotterdam 3015 GJ, The Netherlands
\end{abstract}

\begin{abstract}
Herein, we determined the contribution of mechanical ventilation, hyperoxia and inflammation, individually or combined, to the cytokine/chemokine response of the neonatal lung. Eight-dayold rats were ventilated for $8 \mathrm{~h}$ with low $(\sim 3.5 \mathrm{~mL} / \mathrm{kg})$, moderate $(\sim 12.5 \mathrm{~mL} / \mathrm{kg})$, or high $(\sim 25 \mathrm{~mL} / \mathrm{kg})$ tidal volumes $\left(\mathrm{V}_{\mathrm{T}}\right)$ and the cytokine/chemokine response was measured. Next, we tested whether low $-\mathrm{V}_{\mathrm{T}}$ ventilation with $50 \%$ oxygen or a preexisting inflammation induced by lipopolysaccharide (LPS) would modify this response. High-, moderate-, and low- $\mathrm{V}_{\mathrm{T}}$ ventilation significantly elevated CXCL-2 and IL-6 mRNA levels. Low- $\mathrm{V}_{\mathrm{T}}$ ventilation with $50 \%$ oxygen significantly increased IL-6 and CXCL-2 expression versus low- $\mathrm{V}_{\mathrm{T}}$ ventilation alone. LPS pretreatment combined with low- $\mathrm{V}_{\mathrm{T}}$ ventilation with $50 \%$ oxygen amplified IL-6 mRNA expression when compared with low $\mathrm{V}_{\mathrm{T}}$ alone or low $\mathrm{V}_{\mathrm{T}}+50 \% \mathrm{O}_{2}$ treatment. In contrast, low $\mathrm{V}_{\mathrm{T}}$ up-regulated CXCL-2 levels were reduced to nonventilated levels when LPS-treated newborn rats were ventilated with $50 \%$ oxygen. Thus, low- $\mathrm{V}_{\mathrm{T}}$ ventilation triggers the expression of acute phase cytokines and CXC chemokines in newborn rat lung, which is amplified by oxygen but not by a preexisting inflammation. Depending on the individual cytokine or chemokine, the combination of both oxygen and inflammation intensifies or abrogates the low $\mathrm{V}_{\mathrm{T}}$-induced inflammatory response. (Pediatr Res 68: 63-69, 2010)
\end{abstract}

$\mathrm{B}$ ronchopulmonary dysplasia (BPD) remains the most important cause of respiratory morbidity in very low birth weight infants. Mechanical ventilation (MV), intra-uterine infections and oxidative stress up-regulate proinflammatory cytokines/chemokines including IL-1 $\beta$, IL-6, and IL-8 (1). Elevated concentrations of these cytokines/chemokines in amniotic fluid and bronchoalveolar lavage fluid (BALF) have been associated with BPD $(2,3)$. The contribution of each risk factor, alone or combined, to the inflammatory response remains to be determined.

Ample animal studies have suggested that high frequency oscillatory ventilation (HFOV) is less injurious compared with conventional ventilation (CMV) $(4,5)$. However, in the baboon model of BPD impaired alveolarization and capillary development occurred in spite of appropriate oxygenation and

Received January 14, 2010; accepted March 29, 2010.

Correspondence: Martin Post, Ph.D., Lung Biology Research, Physiology and Experimental Medicine Program, Hospital for Sick Children Research Institute, 555 University Avenue, Toronto, Ontario M5G 1X8; e-mail: martin.post@sickkids.ca

Supported by operating grants (MOP-15272) from the Canadian Institute of Health Research and the Sophia Children's Hospital Fund (SSWO) and infrastructure grants (CCURE, CSCCD) from the Canadian Foundation for Innovation. M.P. holds a Canadian Research Chair in Fetal, Neonatal and Maternal Health. use of HFOV (4). MV with moderate and high tidal volumes increased lung cytokine/chemokine response to systemic endotoxin in rabbits (6) and newborn rats (7). Oxidant injury alone can produce the pathologic features of BPD (8). Inflammatory cells such as monocytes and neutrophils are primary contributors to the oxygen-induced lung injury $(9,10)$. Other animal studies have investigated the contributions of oxygen exposure and MV alone or in combination. In term ventilated piglets hyperoxia caused less lung damage than hyperoxia combined with hyperventilation but more than hyperventilation alone (11). Premature baboons ventilated with the minimum necessary supplemental oxygen had significant less damage than those ventilated with $100 \%$ oxygen (12), but alveolarization and capillary development was still impaired (4).

To our knowledge, no previous study has evaluated the combination of MV, hyperoxia, and inflammation. Therefore, we first assessed the effect of low, moderate, and high tidal volume $\left(\mathrm{V}_{\mathrm{T}}\right)$ ventilation on cytokine/chemokine production. To mimic the clinical situation we used a newborn rat model (7). Rat lungs at birth have a saccular appearance, similar to the preterm neonate, and alveolarization in rats occurs postnatally between $\mathrm{P} 4$ and $\mathrm{P} 21$. High- $\mathrm{V}_{\mathrm{T}}$ ventilation has been reported to cause injury in newborn rat lung $(13,14)$ and was included as positive control. We hypothesized that continuous cyclic (over)stretching of the primitive air sacs would adversely affect cytokine/chemokine production and the adverse effect would be stretch-amplitude dependent. Second, we assessed the effect of low- $\mathrm{V}_{\mathrm{T}}$ ventilation with controlled oxygen superimposed on a systemic inflammation on cytokine/ chemokine production. To induce a mild systemic inflammation, we pretreated the newborn rats with lipopolysaccharide (LPS) (7). We hypothesized that low- $\mathrm{V}_{\mathrm{T}}$ ventilation with $50 \%$ oxygen superimposed on a relatively mild systemic inflammation would enhance the adverse inflammatory mediator production by low tidal volume alone.

\footnotetext{
Abbreviations: $\mathbf{V}_{\mathbf{T}}$, tidal volume; BPD, bronchopulmonary dysplasia; BALF, bronchoalveolar lavage; HFOV, high frequency oscillatory ventilation; LPS, lipopolysaccharide; NV, non-ventilated; MV, mechanical ventilation; $\mathbf{L V}_{\mathbf{T}}, \mathbf{M V}$ with low tidal volume; $\mathbf{M V}_{\mathbf{T}}, \mathbf{M V}$ with moderate tidal volume; $\mathbf{H V}_{\mathbf{T}}$, MV with high tidal volume; $\mathbf{L V}_{\mathbf{T}}+\mathbf{L P S}, \mathrm{LV}_{\mathrm{T}}$ after exposure to LPS; $\mathbf{L} \mathbf{V}_{\mathbf{T}}+\mathbf{O}_{\mathbf{2}}, \mathrm{LV}_{\mathrm{T}}$ and $50 \%$ oxygen; $\mathbf{L} \mathbf{V}_{\mathbf{T}}+\mathbf{L P S} / \mathbf{O}_{\mathbf{2}}, \mathrm{LV}_{\mathrm{T}}$ and $50 \%$ oxygen after exposure to LPS; PEEP, positive end expiratory pressure; MPO, myeloperoxidase; CXCL, chemokine (C-X-C motif) ligand
} 


\section{METHODS}

Animals. In two series of experiments, newborn (postnatal d 8) SpraqueDawley rats (average weight $16.7 \pm 1.0 \mathrm{~g}$ ) were ventilated for $8 \mathrm{~h}$ using rodent ventilators (FlexiVent Scireq, Montreal, PQ). After rats were anesthetized by i.p. injection of $30 \mathrm{mg} / \mathrm{kg}$ pentobarbital, a tracheotomy was performed. The trachea was cannulated with a $1-\mathrm{cm} 22 \mathrm{G}$ cannula. Dynamic compliance was estimated from data obtained during a single-frequency forced oscillation maneuver, using a mathematical model-fitting technique according to the specifications of Scireq Inc. (Montreal, PQ). To determine ventilator settings, we started with the normal breathing frequency of a 8-d-old rat $[\sim 160 /$ min (15) $]$ and adjusted $V_{T}$ and positive end expiratory pressure (PEEP) to achieve normal blood gases. The $\mathrm{V}_{\mathrm{T}}$ and PEEP values for this frequency were $\sim 12.5 \mathrm{~mL} \cdot \mathrm{kg}^{-1}$ and $2 \mathrm{~cm} \mathrm{H}_{2} \mathrm{O}$, respectively. Next, we choose a lower and higher $\mathrm{V}_{\mathrm{T}}$ and adjusted the ventilator frequency accordingly. Increasing the PEEP in the low tidal volume $\left(\mathrm{LV}_{\mathrm{T}}\right)$ group led to increase of $\mathrm{CO}_{2}$ and early death, most likely due to inadvertent PEEP. Animals were monitored by ECG. Rectal temperature was maintained around $37^{\circ} \mathrm{C}$ by using a thermal blanket, lamp and plastic wrap. To prevent spontaneous respiratory efforts $5 \mathrm{mg} / \mathrm{kg}$ pancuronium was administered i.p. Every $2 \mathrm{~h} 0.1 \mathrm{~mL}$ saline was administered to prevent dehydration. At the end of the ventilation period, a blood sample from the carotid artery was taken for blood gas analysis before euthanasia. Lung tissues were processed for histology or fresh frozen for molecular/protein analyses. The study was conducted according to the guidelines of the Canadian Council for Animal Care and with approval of the Animal Care Review Committee of the Hospital for Sick Children.

Series I: different $V_{T}$. Animals were randomly assigned to one of the following four groups: 1) nonventilated (NV) controls; 2) low $\mathrm{V}_{\mathrm{T}}\left(\mathrm{V}_{\mathrm{T}} \sim 3.5\right.$ $\mathrm{mL} / \mathrm{kg}$, frequency $600 / \mathrm{min}$, PEEP $\left.\left.0 \mathrm{~cm} \mathrm{H}_{2} \mathrm{O}\right) ; 3\right)$ moderate $\mathrm{V}_{\mathrm{T}}\left(\mathrm{V}_{\mathrm{T}} \sim 12.5\right.$ $\mathrm{mL} / \mathrm{kg}$, frequency 160/min, PEEP $\left.\left.2 \mathrm{~cm} \mathrm{H}_{2} \mathrm{O}\right) ; 4\right)$ high $\mathrm{V}_{\mathrm{T}}\left(\mathrm{V}_{\mathrm{T}} \sim 25 \mathrm{~mL} / \mathrm{kg}\right.$, frequency 20/min, PEEP $2 \mathrm{~cm} \mathrm{H}_{2} \mathrm{O}$ ).

Series II: preexposure to LPS and low- $V_{T}$ ventilation with oxygen. Rats were randomly assigned to injection (i.p.) of either $3 \mathrm{mg} / \mathrm{kg}$ body weight of LPS from E. coli serotype 026:B6 or the same volume of $0.9 \% \mathrm{NaCl}$ (7). Twenty-four hours after treatment animals were randomly assigned to one of the following six groups: 1) NV after $\mathrm{NaCl}$ injection; 2) NV after LPS injection (NV + LPS); 3) low $\mathrm{V}_{\mathrm{T}}\left(\mathrm{V}_{\mathrm{T}} \sim 3.5 \mathrm{~mL} / \mathrm{kg}\right.$, freq. 600/min, PEEP $0 \mathrm{~cm}$ $\mathrm{H}_{2} \mathrm{O}$ ) with room air after $\mathrm{NaCl}$ injection $\left(\mathrm{LV}_{\mathrm{T}}\right)$ : 4) low $\mathrm{V}_{\mathrm{T}}$ with room air after LPS injection $\left.\left(\mathrm{LV}_{\mathrm{T}}+\mathrm{LPS}\right) ; 5\right)$ low $\mathrm{V}_{\mathrm{T}}$ with $50 \%$ oxygen after $\mathrm{NaCl}$ injection $\left(\mathrm{LV}_{\mathrm{T}}+\mathrm{O}_{2}\right)$; 6) Low $\mathrm{V}_{\mathrm{T}}$ with $50 \%$ oxygen after LPS injection $\left(\mathrm{LV}_{\mathrm{T}}+\right.$ $\left.\mathrm{LPS} / \mathrm{O}_{2}\right)$.

Immunohistochemistry. After flushing lungs were infused in situ with $4 \%$ ( vol/vol) paraformaldehyde (PFA) in PBS with a constant pressure of $20 \mathrm{~cm}$ $\mathrm{H}_{2} \mathrm{O}$ to equalize filling pressure over the entire lung. Under these constant pressure conditions the cannula was removed and the trachea immediately ligated. The excised lung tissue was immersed in 4\% (vol/vol) PFA in PBS overnight and then dehydrated in an ethanol/xylene series and embedded in paraffin. Five micron sections were deparaffinized, rehydrated in a graded series of ethanol. After antigen retrieval by heating in $10 \mathrm{mM}$ sodium citrate $\mathrm{pH}$ 6.0, endogenous peroxidase quenching and blocking with NGS/BSA, sections were stained with 1:200 diluted mouse anti-CD68 (Serotec, Raleigh, NC) and 1: 100 diluted rabbit anti-myeloperoxidase (MPO) antibodies (Lab Vision Corporation, Fremont, Canada), using the avidin-biotin (ABC) immunoperoxidase method. Biotinylated rabbit anti-mouse IgG or goat anti-rabbit $\mathrm{IgG}$ were used as secondary antibodies, respectively. All sections were counterstained with hematoxylin.

Quantitative RT-PCR. Total RNA was extracted from lung tissues and reverse transcribed. cDNA was amplified for our target genes (IL-1 $\beta$ 'IL-6, IL-10, CXCL-2 GRO2/MIP-2: macrophage inflammatory protein-2, a functional rodent homolog of human IL-8) and $18 \mathrm{~S}$ as previously described $(7,10)$. For relative quantification, polymerase chain reaction signals were compared between groups after normalization using $18 \mathrm{~S}$ as an internal reference. Fold change was calculated.

Cytokine protein measurement in BALF. Lungs were infused with $0.5 \mathrm{~mL}$ of saline, followed by withdrawal and re-infusion two more times (7). Total protein was determined and IL- $1 \beta$, IL- 6 and CXCL-1 (also known as GRO1/ KC) were measured in BALF using multiplex immunoassays for Luminex technology (7). CXCL-1 was measured because of lack of CXCL-2 detection kit for the Luminex system.

Statistical analysis. Stated otherwise all data are presented as mean \pm SD. Data were analyzed using SPSS software version 15 (SPSS Inc, Chicago, IL). Depending on the distribution and the homogeneity of variation within the groups, statistical significance $(p<0.05)$ was determined by using either one-way ANOVA, or Kruskal-Wallis test. Posthoc analysis was performed using Duncan's multiple-range test (data presented as mean $\pm \mathrm{SD}$ ) or Mann-Whitney test (data presented as median and interquartile range). Be- cause data of $\mathrm{NV}$ and $\mathrm{LV}_{\mathrm{T}}$ groups of series I and II were similar, they were combined in the analysis.

\section{RESULTS}

\section{Series I: different $V_{T}$}

Physiologic data. Blood gases were in the normal range after $8 \mathrm{~h}$ of ventilation with different $\mathrm{V}_{\mathrm{T}}$ (Table 1). Ventilator set $\mathrm{V}_{\mathrm{T}}$ differed from inspired $\mathrm{V}_{\mathrm{T}}$, namely 6,16 , and $40 \mathrm{~mL} / \mathrm{kg}$ for low, moderate, and high $\mathrm{V}_{\mathrm{T}}$, respectively. Dynamic compliance of the respiratory system is shown in Figure 1. Dynamic compliance of animals ventilated with high $\mathrm{V}_{\mathrm{T}}$ significantly increased within minutes of ventilation and then remained stable for the rest of the experiment, indicative of larger airspaces and loss of tissue recoil due to hyperinflation (Fig. 2). Overall mortality during ventilation was $16.4 \%$ with no differences between $\mathrm{V}_{\mathrm{T}}$ groups. No autopsy was performed, and electrolytes were not measured.

Inflammatory cells in lung. High- $\mathrm{V}_{\mathrm{T}}$ ventilation was associated with a significant increase of MPO-positive neutrophils in comparison with $\mathrm{NV}, \mathrm{LV}_{\mathrm{T}}$, and $\mathrm{MV}_{\mathrm{T}}$. To a lesser extent, moderate- $\mathrm{V}_{\mathrm{T}}$ ventilation also increased the number of MPO-positive neutrophils (mainly in the alveolar space) in comparison with $\mathrm{LV}_{\mathrm{T}}$ (Table 2). $\mathrm{HV}_{\mathrm{T}}$ increased the number of neutrophils in both lung parenchyma and alveolar space. The number of macrophages (CD-68 antigen) did not alter among the ventilation groups (Table 2).

Cytokine mRNA expression. The effect of ventilation with different $\mathrm{V}_{\mathrm{T}}$ on IL-1 $\beta$, IL-6, CXCL-2, and IL-10 mRNA expression is shown in Figure 3. Low- $\mathrm{V}_{\mathrm{T}}$ ventilation increased

Table 1. Blood gas analysis after 8 hours of mechanical ventilation of 8-d newborn rats with different tidal volumes

\begin{tabular}{lccc}
\hline & \multicolumn{3}{c}{ Tidal volume } \\
\cline { 2 - 4 } & $\mathrm{LV}_{\mathrm{T}}$ & $\mathrm{MV}_{\mathrm{T}}$ & $\mathrm{HV}_{\mathrm{T}}$ \\
\hline $\mathrm{pH}$ & $7.39 \pm 0.08$ & $7.39 \pm 0.02$ & $7.39 \pm 0.04$ \\
$\mathrm{PaCO}_{2}(\mathrm{~mm} \mathrm{Hg})$ & $45 \pm 4.4$ & $44 \pm 6.4$ & $42 \pm 2.2$ \\
$\mathrm{PaO}_{2}(\mathrm{~mm} \mathrm{Hg})$ & $72 \pm 13.8$ & $83 \pm 8.1$ & $91 \pm 9.8$ \\
$\mathrm{Saturation} \%)$ & $95 \pm 3.2$ & $96 \pm 0.8$ & $97 \pm 1.2$ \\
\hline
\end{tabular}

Data are mean $\pm \mathrm{SD}, n=4$ animals per group.

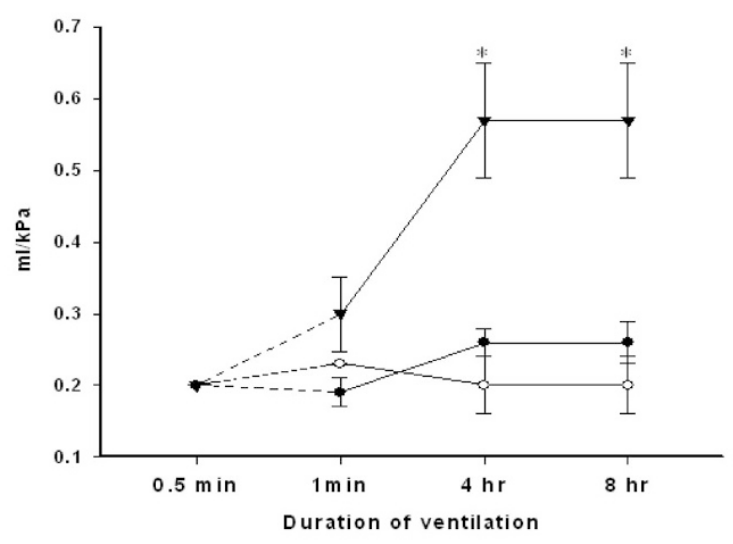

Figure 1. Dynamic compliance of 8-d newborn rats ventilated with room air and low $\mathrm{V}_{\mathrm{T}}(\mathrm{O})$, moderate $\mathrm{V}_{\mathrm{T}}(\bullet)$, and high $\mathrm{V}_{\mathrm{T}}(\boldsymbol{\nabla})$. Analysis of variance of parameters was assessed using 1-way ANOVA. Data are mean $\pm \mathrm{SD}, n=8$ animals per group. ${ }^{*} p<0.05 v s$ ventilation for $1 \mathrm{~min}$. Dash lines are extrapolated. 


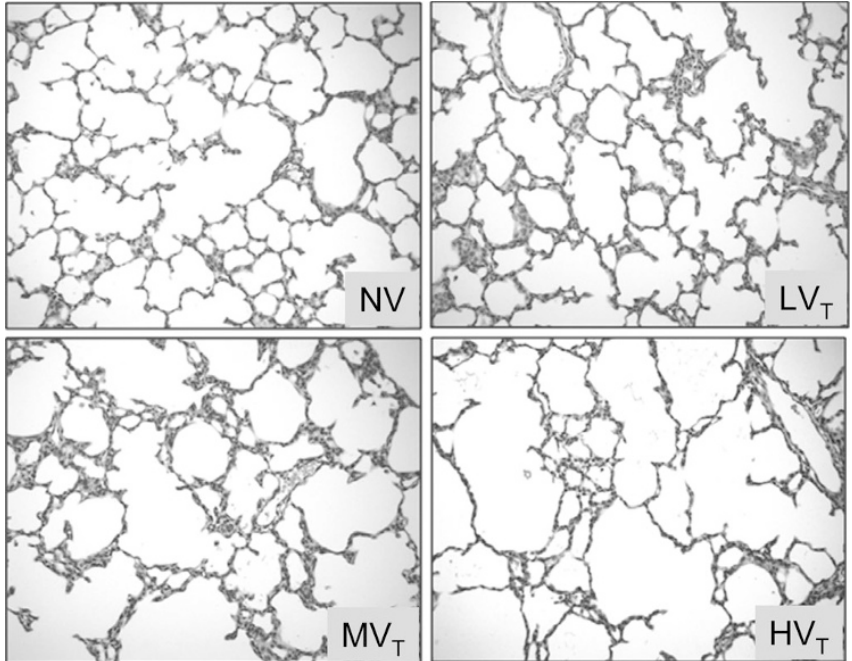

Figure 2. Representative sections of ventilated lungs stained with hematoxylin and eosin. Low-, moderate-, and high- $\mathrm{V}_{\mathrm{T}}$ ventilation of 8-d neonatal rats do not show any areas of atelectasis, indicating no differences in lung recruitment. Air spaces are larger after high- $\mathrm{V}_{\mathrm{T}}$ ventilation due to hyperinflation.

Table 2. Effect of low, moderate, and high $V_{T}$ ventilation on number of myeloperoxidase- and CD68-positive inflammatory cells in lungs of 8-d newborn rats

\begin{tabular}{lrccc}
\hline & \multicolumn{4}{c}{ Tidal volume } \\
\cline { 2 - 5 } & \multicolumn{1}{c}{$\mathrm{NV}$} & \multicolumn{1}{c}{$\mathrm{LV}_{\mathrm{T}}$} & $\mathrm{MV}_{\mathrm{T}}$ & $\mathrm{HV}_{\mathrm{T}}$ \\
\hline MPO total & $19.6 \pm 8.4$ & $14.0 \pm 5.6$ & $28.0 \pm 3.0^{*}$ & $58.3 \pm 4.2 \S$ \\
MPO tissue & $9.7 \pm 3.5$ & $10.8 \pm 6.3$ & $8.3 \pm 0.3$ & $32.3 \pm 13.1 \S$ \\
MPO air & $10.0 \pm 5.6$ & $3.3 \pm 2.8$ & $19.7 \pm 3.3 *$ & $26.0 \pm 11.1^{*}$ \\
CD 68 & $4.9 \pm 0.9$ & $6.1 \pm 0.88$ & $3.7 \pm 0.4$ & $4.4 \pm 1.0$ \\
\hline
\end{tabular}

Number of immunopositive cells per unit area $(40 \times$ high power field) are mean $\pm \mathrm{SD}, n=5$ fields per slide, three slides per animal and four animals per group.

${ }^{*} p<0.05$ vs $\mathrm{LV}_{\mathrm{T}}$ and $\mathrm{HV}_{\mathrm{T}}$

$\uparrow p<0.05$ vs $\mathrm{NV}$ and $\mathrm{LV}_{\mathrm{T}}$.

$\ddagger p<0.05$ vs other groups.

CXCL-2 and IL-6 mRNA levels versus NV animals $(p<$ $0.05)$, whereas those of IL- $1 \beta$ and IL-10 were not altered. Moderate- $\mathrm{V}_{\mathrm{T}}$ ventilation seemed to further increase the expression of CXCL-2 versus NV animals and that of IL-6 versus $\mathrm{NV}$ and low- $\mathrm{V}_{\mathrm{T}}$ rat pups, but the differences were not significant. Message levels of IL- $1 \beta$ and IL-10 were also not altered by $M V_{T}$. High- $V_{T}$ ventilation significantly increased mRNA expression of IL- $1 \beta$, CXCL-2, and IL-6, but not IL-10, versus all other groups $(p<0.05)$.

Cytokines in BALF. Table 3 shows the amount of IL- $1 \beta$, IL-6, and CXCL-1 in BALF after $8 \mathrm{~h}$ of ventilation. The volume of lavaged material recovered from each animal $(0.29 \pm 0.08 \mathrm{~mL})$ and BALF total protein content $(0.22 \pm$ $0.08 \mu \mathrm{g} / \mu \mathrm{L}$ ) did not differ significantly between treatment groups There was a trend toward an increase of IL- $1 \beta$ and IL-6 with increasing $V_{T}$. However, only $\mathrm{HV}_{\mathrm{T}}$ ventilation significantly increased IL- $1 \beta$ and CXCL- 1 levels.

Series II: pre-exposure to LPS and low- $V_{T}$ ventilation with oxygen

Physiologic data. Ventilation for $8 \mathrm{~h}$ with low $\mathrm{V}_{\mathrm{T}}$ with room air after exposure to LPS $\left(\mathrm{LV}_{\mathrm{T}}+\mathrm{LPS}\right)$, ventilation with $50 \%$ oxygen $\left(\mathrm{LV}_{\mathrm{T}}+\mathrm{O}_{2}\right)$, and ventilation with oxygen after

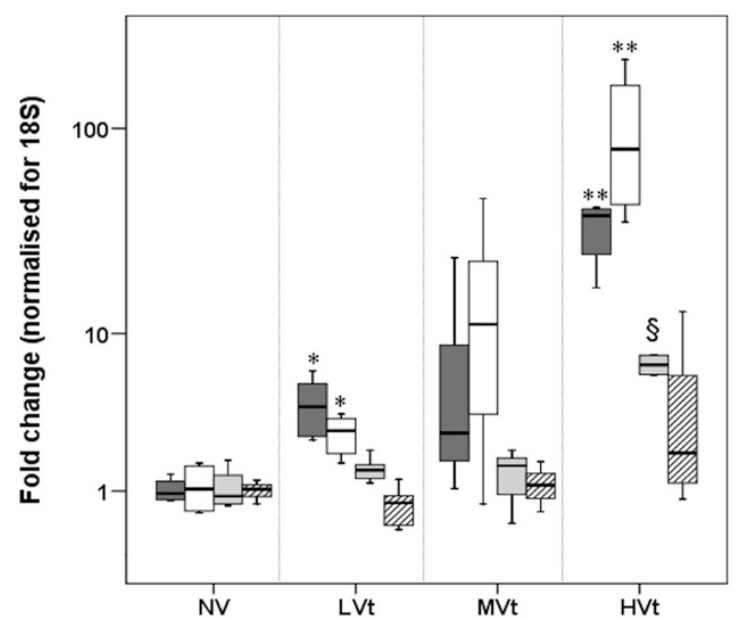

Figure 3. Effect of low-, moderate- and high- $\mathrm{V}_{\mathrm{T}}$ ventilation on proinflammatory gene expression in lungs of 8-d newborn rats. $\mathbf{a}=$ CXCL-2, $\square=\mathrm{IL}-6, \square=$ $\mathrm{IL}-1 \beta, \mathbb{Z}=\mathrm{IL}-10$. Medians with 25 th and 75 th quartiles are shown; bars are 5 th and 95th percentiles. NV and $\mathrm{LV}_{\mathrm{T}}: n=8 ; \mathrm{MV}_{\mathrm{T}}: n=6 ; \mathrm{HV}_{\mathrm{T}}: n=4 .{ }^{*} p<0.05$ vs $\mathrm{NV}$ group, $* * p<0.05$ vs $\mathrm{NV}$ and $\mathrm{LV}_{\mathrm{T}}$ group, $\S p<0.05$ vs other groups.

Table 3. Effect of low, moderate, and high $V_{T}$ ventilation on BALF cytokine protein content of 8-d newborn rats

\begin{tabular}{lcccc}
\hline Cytokine & $\mathrm{NV}$ & $\mathrm{LV}_{\mathrm{T}}$ & $\mathrm{MV}_{\mathrm{T}}$ & $\mathrm{HV}_{\mathrm{T}}$ \\
\hline IL-6 & $0.7(0.6-1.1)$ & $2.2(1.1-4.9)$ & $8.0(3.3-11.7)$ & $5.2(1.7-21.0)$ \\
IL-1 $\beta$ & $0.13(0.1-0.2)$ & $0.2(0.17-0.4)$ & $0.33(0.24-0.43)$ & $1.0(0.94-1.5)^{*}$ \\
CXCL-1 & $10.3(7.5-12.3)$ & $9(8.5-9.8)$ & $7.9(3.7-12.0)$ & $14.9(12.3-20.7) \dagger$ \\
\hline
\end{tabular}

Concentrations are expressed as pg cytokine/100 pg of total BALF protein. Data are expressed as medians with 25th and 75th quartiles, $n=8$ for groups $\mathrm{NV}$ and $\mathrm{LV}_{\mathrm{T}}, n=4$ animals for other groups.

${ }^{*} p<0.05$ vs $\mathrm{NV}, \mathrm{LV}_{\mathrm{T}}$, and $\mathrm{MV}_{\mathrm{T}}$

$\dagger p<0.05$ vs $\mathrm{LV}_{\mathrm{T}}$ and $\mathrm{MV}_{\mathrm{T}}$.

Table 4. Blood gas analysis after 8 h of mechanical ventilation of 8-d newborn rats after exposure to endotoxin and/or 50\% oxygen

\begin{tabular}{lcllc}
\hline & \multicolumn{4}{c}{ Tidal volume } \\
\cline { 2 - 5 } & $\mathrm{LV}_{\mathrm{T}}$ & $\mathrm{LV}_{\mathrm{T}}+\mathrm{LPS}$ & $\mathrm{LV}_{\mathrm{T}}+\mathrm{O}_{2}$ & $\mathrm{LV}_{\mathrm{T}}+\mathrm{LPS} / \mathrm{O}_{2}$ \\
\hline $\mathrm{pH}$ & $7.39 \pm 0.08$ & $7.40 \pm 0.04$ & $7.32 \pm 0.18$ & $7.30 \pm 0.08$ \\
$\mathrm{PaCO}_{2}(\mathrm{~mm} \mathrm{Hg})$ & $45 \pm 4.4$ & $36.0 \pm 3.7$ & $58.3 \pm 14.4$ & $54.3 \pm 16.6$ \\
$\mathrm{PaO}_{2}(\mathrm{~mm} \mathrm{Hg})$ & $72 \pm 13.8$ & $87.7 \pm 6.6^{*}$ & $131.0 \pm 42.5^{*}$ & $167.0 \pm 40.4 \dagger$ \\
Saturation (\%) & $95 \pm 3.2$ & $96.5 \pm 1.2$ & $96.4 \pm 3.6$ & $98.4 \pm 1.6$ \\
\hline
\end{tabular}

Data are mean $\pm \mathrm{SD}, n=4$ animals per group.

$* p<0.05 v s$ animals ventilated with $\mathrm{LV}_{\mathrm{T}}$.

$\dagger p<0.05$ vs animals ventilated with $\mathrm{LV}_{\mathrm{T}}$ and $\mathrm{LV}_{\mathrm{T}}+\mathrm{LPS}$.

exposure to LPS $\left(\mathrm{LV}_{\mathrm{T}}+\mathrm{LPS} / \mathrm{O}_{2}\right)$ resulted in normal $\mathrm{pH}$ and $\mathrm{PaCO}_{2}$ (Table 4). Low- $\mathrm{V}_{\mathrm{T}}$ ventilation with room air after exposure to LPS ( $\mathrm{LV}_{\mathrm{T}}+\mathrm{LPS}$ ) and ventilation with $50 \%$ oxygen $\left(\mathrm{LV}_{\mathrm{T}}+\mathrm{O}_{2}\right)$ significantly increased the $\mathrm{PaO}_{2}$ when compared with ventilation with room air $\left(\mathrm{LV}_{\mathrm{T}}\right)$. The combination of ventilation with oxygen and exposure to LPS $\left(\mathrm{LV}_{\mathrm{T}}+\mathrm{LPS} / \mathrm{O}_{2}\right)$ further increased $\mathrm{PaO}_{2}$ versus $\mathrm{LV}_{\mathrm{T}}$ and $\mathrm{LV}_{\mathrm{T}}$ + LPS groups $(p<0.05)$. Mean airway pressures and peak pressures remained stable during the ventilation period and were not different between groups. Dynamic compliance of the respiratory system is shown in Figure 4. Ventilation with room air after exposure to LPS $\left(\mathrm{LV}_{\mathrm{T}}+\mathrm{LPS}\right)$, ventilation with $50 \%$ oxygen $\left(\mathrm{LV}_{\mathrm{T}}+\mathrm{O}_{2}\right)$, and ventilation with oxygen after exposure to LPS $\left(\mathrm{LV}_{\mathrm{T}}+\mathrm{LPS} / \mathrm{O}_{2}\right)$ significantly decreased the 


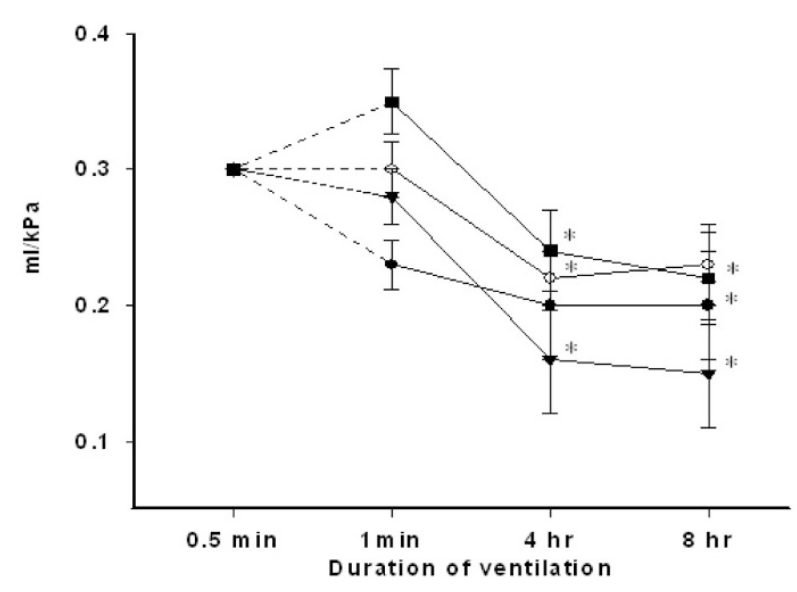

Figure 4. Dynamic compliance of 8-d newborn rats ventilated with low $V_{T}$ and room air $(\bullet)$, low $\mathrm{V}_{\mathrm{T}}$ and room air after exposure to LPS $(0)$, low $\mathrm{V}_{\mathrm{T}}$ and $50 \%$ oxygen $(\nabla)$ and low $\mathrm{V}_{\mathrm{T}}$ with $50 \%$ oxygen after exposure to LPS $(\nabla)$. Data are mean $\pm \mathrm{SD}, n=8$ animals per group. The dash lines are extrapolated. $* p<0.05 v s$ ventilation for $1 \mathrm{~min}$.

Table 5. Combined effect of endotoxin, oxygen, and low $V_{T}$ ventilation on number of myeloperoxidase- and CD68-positive inflammatory cells in lungs of 8-d newborn rats

\begin{tabular}{lccc}
\hline & \multicolumn{3}{c}{ Tidal volume } \\
\cline { 2 - 4 } & $\mathrm{NV}$ & $\mathrm{NV}+\mathrm{LPS}$ & $\mathrm{LV}_{\mathrm{T}}$ \\
\hline MPO total & $19.6 \pm 8.4$ & $211.0 \pm 74.0^{*}$ & $14.0 \pm 5.6$ \\
MPO tissue & $9.7 \pm 3.5$ & $187.3 \pm 73.3^{*}$ & $10.8 \pm 6.3$ \\
MPO air & $10.0 \pm 5.6$ & $23.8 \pm 2 . \dagger^{\dagger}$ & $3.3 \pm 2.8$ \\
$\mathrm{CD} 68$ & $4.9 \pm 0.9$ & $11.8 \pm 0.33^{*}$ & $6.1 \pm 0.88$ \\
& $\mathrm{LV} \mathrm{T}_{\mathrm{T}}+\mathrm{LPS}$ & $\mathrm{LV}_{\mathrm{T}}+\mathrm{O}_{2}$ & $\mathrm{LV}_{\mathrm{T}}+\mathrm{LPS} / \mathrm{O}_{2}$ \\
\hline MPO total & $186.0 \pm 117.5^{*}$ & $12.0 \pm 1.4$ & $188.7 \pm 257.9 \S$ \\
MPO tissue & $169.3 \pm 114.3^{*}$ & $8.3 \pm 2.9$ & $176.8 \pm 259.3 \S$ \\
MPO air & $16.7 \pm 9.7 \neq$ & $3.7 \pm 3.5$ & $11.8 \pm 3.4^{*}$ \\
CD 68 & $2.5 \pm 2.8^{*}$ & $7.4 \pm 0.6$ & $13.4 \pm 2.0^{*}$ \\
\hline
\end{tabular}

Number of immunopositive cells per unit area $(40 \times$ high power field $)$ are mean $\pm \mathrm{SD}, n=5$ fields per slide, three slides per animal and four animals per group. $\mathrm{LV}_{\mathrm{T}}+\mathrm{O}_{2}$ group was not compared with $\mathrm{NV}+\mathrm{LPS}$ and $\mathrm{LV}_{\mathrm{T}}+$ LPS groups.

$* p<0.05$ vs $\mathrm{NV}$ and $\mathrm{LV}_{\mathrm{T}}$.

$\dagger p<0.05$ vs $\mathrm{NV}, \mathrm{LV}_{\mathrm{T}}$, and LVT $+\mathrm{LPS} / \mathrm{O}_{2}$.

$\ddagger p<0.05$ vs $\mathrm{LV}_{\mathrm{T}}$.

$\S p<0.05$ vs $\mathrm{NV}, \mathrm{LV}_{\mathrm{T}}$, and $\mathrm{LV}_{\mathrm{T}}+\mathrm{O}_{2}$. dynamic compliance after $4 \mathrm{~h}$ of ventilation. Loss of compliance can be explained by increase of stiffness of the lung as a result of lung injury. No further worsening of dynamic compliance was seen during the last $4 \mathrm{~h}$ of ventilation. Overall mortality during ventilation was $8.1 \%$ with no differences between the four groups. No autopsy was performed.

Inflammatory cells in lung. Mean values and ranges for the number of macrophages (CD68-antigen) and MPOpositive neutrophils per unit area are shown in Table 5. Exposure to LPS, independent of ventilation with or without oxygen, was associated with a significant increase of MPOpositive neutrophils as well as CD-68 positive macrophages. The number of neutrophils was profoundly increased in the parenchyma and to a lesser extent in the alveolar space.

Cytokine mRNA expression. The effect of LPS, $L_{T}$ ventilation and $L V_{T}$ ventilation after exposure to $L P S\left(\mathrm{LV}_{\mathrm{T}}+\right.$ LPS) on IL-1 $\beta$, IL-6, CXCL-2, and IL-10 mRNA expression is shown in Figure 5A. LPS significantly increased the expression of IL- 6 and IL- $1 \beta$ even $24 \mathrm{~h}$ after administration when compared with saline treated animals (LPS $>\mathrm{NV}, p<0.05$ ). However, mRNA expression of CXCL-2 and IL-10 was not altered by the LPS pretreatment. The combination of $\mathrm{LV}_{\mathrm{T}}$ and LPS pretreatment did not increase the expression of IL-6 and CXCL-2 above that observed in animals ventilated with $\mathrm{LV}_{\mathrm{T}}$ $\left(\mathrm{LV}_{\mathrm{T}} \approx \mathrm{LV}_{\mathrm{T}}+\mathrm{LPS}>\mathrm{NV} ; p<0.05\right)$ and decreased IL-6 mRNA levels compared with LPS treatment alone (LPS > $\left.\mathrm{LV}_{\mathrm{T}}+\mathrm{LPS}, p<0.05\right)$. $\mathrm{LV}_{\mathrm{T}}$ ventilation after exposure to LPS significantly decreased the expression of IL-10 mRNA $(p<$ $0.05)$. Figure $5 B$ shows the effect of ventilation with room air or $50 \%$ oxygen on IL- $1 \beta$, IL- 6 , CXCL-2, and IL-10 mRNA expression. As shown in Series $\mathrm{I}$, low $\mathrm{V}_{\mathrm{T}}$ ventilation with room air increased the expression of IL-6 and CXCL-2 versus $\mathrm{NV}$ controls. Ventilation with $50 \%$ oxygen further increased the message levels of both cytokines $\left(\mathrm{LV}_{\mathrm{T}}+\mathrm{O}_{2}>\mathrm{LV}_{\mathrm{T}}, p<\right.$ $0.05)$. The expression of IL- $1 \beta$ and IL-10 mRNA was not altered by ventilation with room air or oxygen. Ventilation with $50 \% \mathrm{O}_{2}$ after LPS pretreatment (Fig. 5C) resulted in the greatest increase in IL-6 mRNA levels $\left(\mathrm{LV}_{\mathrm{T}}+\mathrm{LPS} / \mathrm{O}_{2}>\right.$ $\left.\mathrm{NV}+\mathrm{LPS}>\mathrm{LV}_{\mathrm{T}}+\mathrm{LPS} \approx \mathrm{LV}_{\mathrm{T}}+\mathrm{O}_{2}>\mathrm{LV}_{\mathrm{T}}>\mathrm{NV}\right)(\mathrm{Fig}$.
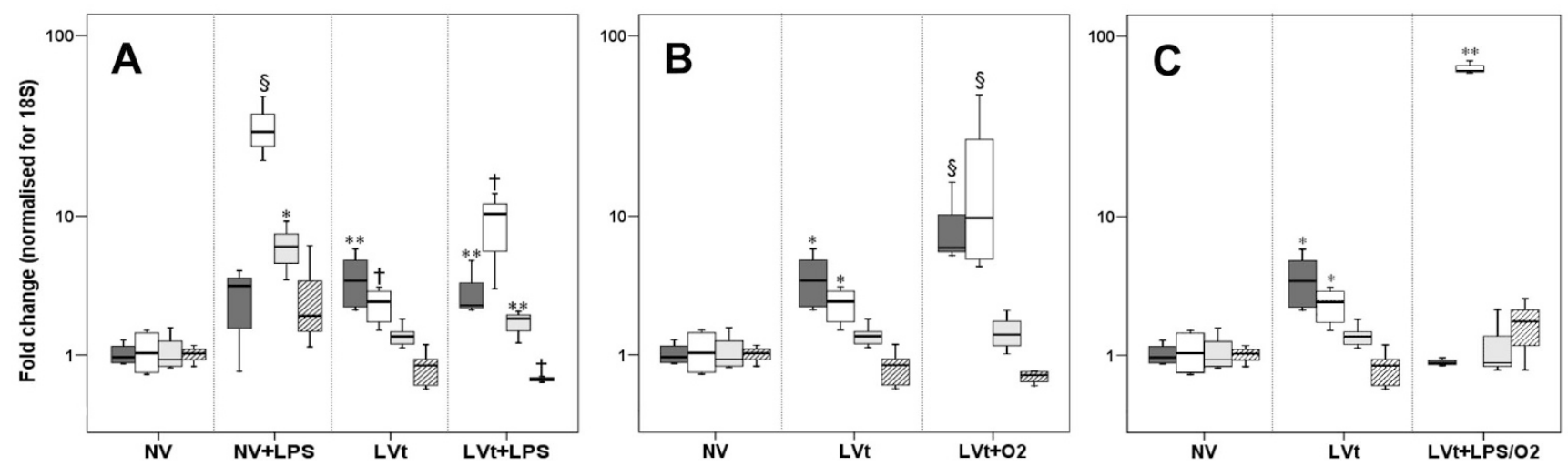

Figure 5. Effect of endotoxin and oxygen on low $-\mathrm{V}_{\mathrm{T}}$ ventilation triggered pro-inflammatory gene expression in lungs of 8-d newborn rats. $\square=C X C L-2$, $\square=$ $\mathrm{IL}-6, \square=\mathrm{IL}-1 \beta$, IL-10. Medians with 25th and 75th quartiles are shown, bars are 5th and 95th percentiles. $\mathrm{NV}$ and $\mathrm{LV}_{\mathrm{T}}: n=8 ; \mathrm{NV}+\mathrm{LPS} \mathrm{LV}_{\mathrm{T}}+\mathrm{O}_{2}$ and $\mathrm{LV}_{\mathrm{T}}+\mathrm{LPS}: n=5 ; \mathrm{LV}_{\mathrm{T}}+\mathrm{LPS} / \mathrm{O}_{2}: n=6$. A, Low $\mathrm{V}_{\mathrm{T}}$ after exposure to LPS. ${ }^{*} p<0.05 v s \mathrm{NV}$ and $\mathrm{LV}_{\mathrm{T}}, * * p<0.05 v s \mathrm{NV}, \S p<0.05 v s \mathrm{NV}, \mathrm{LV}$, and $\mathrm{LV}_{\mathrm{T}}+\mathrm{LPS}, \uparrow p<0.05 v s \mathrm{NV}$ and $\mathrm{NV}+$ LPS. $B$, Low- $\mathrm{V}_{\mathrm{T}}$ ventilation with $50 \%$ oxygen. $* p<0.05 v s \mathrm{NV}$ and $\mathrm{LV}_{\mathrm{T}}+\mathrm{O}_{2}, \S p<0.05 v s \mathrm{NV}$ and $\mathrm{V}_{\mathrm{T}}$. $C$, Low- $\mathrm{V}_{\mathrm{T}}$ ventilation with $50 \%$ oxygen after LPS exposure. ${ }^{*} p<0.05 v s \mathrm{NV}$ and $\mathrm{LV}_{\mathrm{T}}+\mathrm{LPS}_{2} \mathrm{O}_{2}, * * p<0.05 v s \mathrm{NV}$ and $\mathrm{LV}_{\mathrm{T}}$. 
Table 6. Combined effect of endotoxin, oxygen, and low $V_{T}$ ventilation on BALF cytokine protein content of 8 -d newborn rats

\begin{tabular}{lccc}
\hline Cytokine & $\mathrm{NV}$ & $\mathrm{NV}+\mathrm{LPS}$ & $\mathrm{LV}_{\mathrm{T}}$ \\
\hline IL-6 & $0.7(0.6-1.1)$ & $0.7(0.5-1.1)$ & $2.2(1.1 .-4.9)$ \\
$\mathrm{IL}-1 \beta$ & $0.13(0.1-0.2)$ & $0.07(0.06-0.08)^{*}$ & $0.2(0.17-0.4)$ \\
$\mathrm{GRO} / \mathrm{KC}$ & $10.3(7.5-12.3)$ & $22.2(18.3-23.4) \dagger$ & $9(8.5-9.8)$ \\
& $\mathrm{LV}_{\mathrm{T}}+\mathrm{LPS}$ & $\mathrm{LV}_{\mathrm{T}}+\mathrm{O}_{2}$ & $\mathrm{LV}_{\mathrm{T}}+\mathrm{LPS} / \mathrm{O}_{2}$ \\
\hline $\mathrm{IL}-6$ & $3.5(2.6-3.8) \ddagger$ & $2.1(1.3-2.9) \S$ & $3.0 \pm 0.68 \ddagger$ \\
$\mathrm{IL}-1 \beta$ & $0.22(0.18-0.23)$ & $0.45(0.38-0.55) \S$ & $0.29(0.25-0.45) \|$ \\
GRO/KC & $15.7(10-21.4) \mathbb{4}$ & $7.6(7.0-9.2)$ & $9.6(7.4-12.2)$ \\
\hline
\end{tabular}

Concentrations are expressed as pg cytokine/100 pg of total BALF protein. Data are expressed as medians with 25th and 75th quartiles, $n=8$ for groups $\mathrm{NV}$ and $\mathrm{LV}_{\mathrm{T}}, n=4$ animals for other groups. $\mathrm{LV}_{\mathrm{T}}+\mathrm{O}_{2}$ group was not compared with NV + LPS and $\mathrm{LV}_{\mathrm{T}}+$ LPS groups.

$* p<0.05$ vs NV, $\mathrm{LV}_{\mathrm{T}}, \mathrm{LV}_{\mathrm{T}}+\mathrm{LPS}$, and $\mathrm{LV}_{\mathrm{T}}+\mathrm{LPS} / \mathrm{O}_{2}$.

$\dagger p<0.05$ vs $\mathrm{NV}, \mathrm{LV}_{\mathrm{T}}$.

$\mathbb{I} p<0.05$ vs $\mathrm{NV}, \mathrm{LV}_{\mathrm{T}}$, and $\mathrm{LV}_{\mathrm{T}}+\mathrm{LPS} / \mathrm{O}_{2}$

$\| p<0.05$ vs NV, NV + LPS, and $\mathrm{LV}_{\mathrm{T}}+$ LPS.

$\S p<0.05$ vs NV.

$\ddagger p<0.05$ vs NV and NV + LPS.

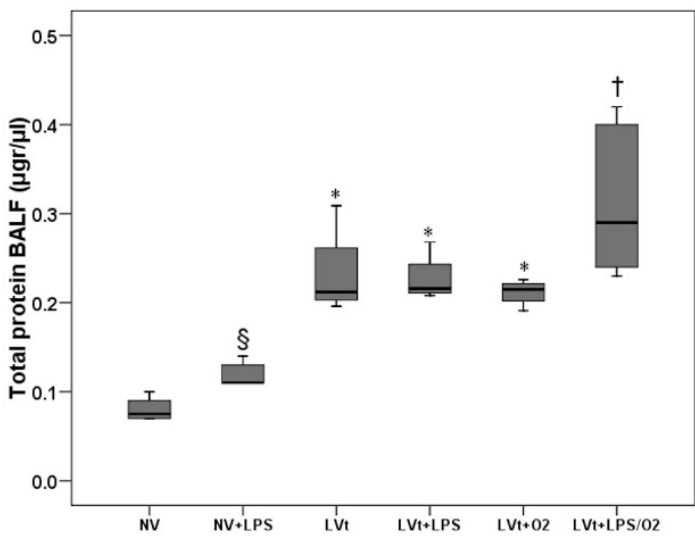

Figure 6. Effects of low- $\mathrm{V}_{\mathrm{T}}$ ventilation, endotoxin, and oxygen on BALF total protein of 8-d newborn rats. Medians with 25th and 75th quartiles are shown, bars are 5th and 95th percentiles. NV and $\mathrm{LV}_{\mathrm{T}}: n=8 ; \mathrm{NV}+\mathrm{LPS}$ : $n=5 ; \mathrm{LV}_{\mathrm{T}}+\mathrm{LPS}$ and $\mathrm{LV}_{\mathrm{T}}+\mathrm{O}_{2}: n=4 ; \mathrm{LV}_{\mathrm{T}}+\mathrm{LPS} / \mathrm{O}_{2}: n=6 . \mathrm{LV}_{\mathrm{T}}+$ $\mathrm{O}_{2}$ group was not compared with $\mathrm{NV}+$ LPS and $\mathrm{LV}_{\mathrm{T}}+$ LPS groups. $* p<$ 0.05 vs NV; $\S p<0.05$ vs $\mathrm{LV}_{\mathrm{T}}, \mathrm{LV}_{\mathrm{T}}+\mathrm{LPS}$, and $\mathrm{LV}_{\mathrm{T}}+\mathrm{LPS} / \mathrm{O}_{2} ; \dagger p<0.05$ vs $\mathrm{LV}_{\mathrm{T}}+\mathrm{LPS}$ and $\mathrm{LV}_{\mathrm{T}}+\mathrm{O}_{2}$.

$5 A-C)$. Interestingly, the combination of ventilation with oxygen and preexposure to LPS decreased the expression of CXCL-2 versus ventilation with room air $\left(\mathrm{LV}_{\mathrm{T}}+\mathrm{LPS} / \mathrm{O}_{2} \approx\right.$ $\mathrm{NV}<\mathrm{LV}_{\mathrm{T}}, p<0.05$ ) (Fig. 5c).

Cytokines in BALF. Table 6 shows the amount of IL- $1 \beta$, IL-6, and CXCL-1 protein in BALF after exposure to either LPS, ventilation with room air or oxygen, ventilation after exposure to LPS or the combination of ventilation with oxygen after exposure to LPS. The amount of BALF total protein was significantly increased after exposure to LPS and further increased after ventilation with room air or oxygen and after ventilation with oxygen of a LPS-exposed lung $\left(\mathrm{LV}_{\mathrm{T}}+\right.$ $\mathrm{LPSLO} 2 \approx \mathrm{LV}_{\mathrm{T}}+\mathrm{O}_{2} \approx \mathrm{LV}_{\mathrm{T}}+\mathrm{LPS} \approx \mathrm{LV}_{\mathrm{T}}>\mathrm{LPS}>\mathrm{NV}$, $p<0.05$ ), consistent with lung injury (Fig. 6). The volume of lavaged material recovered from each animal $(0.31 \pm 0.06$ $\mathrm{mL}$ ) did not differ significantly between the groups. IL-6 content of BALF increased after ventilation with oxygen $\left(\mathrm{LV}_{\mathrm{T}}+\mathrm{O}_{2}>\mathrm{NV}, p<0.05\right)$. An increase was also noted after ventilation of a LPS-exposed lung $\left(\mathrm{LV}_{\mathrm{T}}+\mathrm{LPS}>\mathrm{NV} \approx\right.$ $\mathrm{NV}+$ LPS, $p<0.05$ ). Ventilation of a LPS-exposed lung with oxygen did not further increase the BALF IL-6 content $\left(\mathrm{LV}_{\mathrm{T}}+\mathrm{LPS} / \mathrm{O}_{2} \approx \mathrm{LV}_{\mathrm{T}}+\mathrm{O}_{2} \approx \mathrm{LV}_{\mathrm{T}}+\mathrm{LPS}, p>0.05\right)$. The concentration of IL-1 $\beta$ in BALF only increased after ventilation with oxygen and after ventilation with oxygen after LPS exposure $\left(\mathrm{LV}_{\mathrm{T}}+\mathrm{LPS} / \mathrm{O}_{2} \approx \mathrm{LV}_{\mathrm{T}}+\mathrm{O}_{2}>\mathrm{LV}_{\mathrm{T}}+\mathrm{LPS} \approx\right.$ $\mathrm{LV}_{\mathrm{T}} \approx \mathrm{NV}, p<0.05$ ). Independent of ventilation and oxygen, the concentration of CXCL-1 was increased after exposure to LPS $\left(\mathrm{NV}+\mathrm{LPS} \approx \mathrm{LV}_{\mathrm{T}}+\mathrm{LPS}>\mathrm{LV}_{\mathrm{T}} \approx \mathrm{LV}_{\mathrm{T}}+\mathrm{O}_{2} \approx\right.$ $\left.\mathrm{LV}_{\mathrm{T}}+\mathrm{LPS} / \mathrm{O}_{2,} p>0.05\right)$.

\section{DISCUSSION}

MV, (intrauterine) infection, and oxygen are wellrecognized risk factors for BPD and known to trigger a proinflammatory response. In this study, we demonstrate that low- $\mathrm{V}_{\mathrm{T}}$ ventilation-presumed to be a less injurious form of ventilation-triggers a proinflammatory cytokine/chemokine response in neonatal rats, which is amplified by ventilation with oxygen, but not endotoxin pretreatment. The combination of ventilation with oxygen and endotoxin pretreatment either intensifies or abrogates the low $\mathrm{V}_{\mathrm{T}}$ response, depending on individual cytokine or chemokine.

In the first series of experiments, we assessed the effect of low-, moderate-, and high- $\mathrm{V}_{\mathrm{T}}$ ventilation on pro and antiinflammatory cytokine/chemokine production. Clinical data and experimental studies using premature animal models have compared HFOV (HFOV: low $\mathrm{V}_{\mathrm{T}}$ ) and CMV (CMV: high $\mathrm{V}_{\mathrm{T}}$ ) with respect to pro-inflammatory cytokine/chemokine production and release into the alveolar and/or vascular compartment. Some studies reported findings favoring low- $\mathrm{V}_{\mathrm{T}}$ ventilation $(4,16)$, whereas others did not find any significant differences in cytokine/chemokine production/release between CMV and HFOV ventilation $(17,18)$. In this study, we found a significant increase of mRNA expression of CXCL-2 and IL-6 after $8 \mathrm{~h}$ of low- $\mathrm{V}_{\mathrm{T}}$ ventilation. Further increases were noted with increasing $\mathrm{V}_{\mathrm{T}}$ as reported previously (14). Although there was a tendency to higher concentrations of IL-6 and IL- $1 \beta$ protein in the BAL fluid, we did not find significant increases in total number of inflammatory cells after low $V_{T}$ ventilation. In contrast, moderate and to a higher extent high $-\mathrm{V}_{\mathrm{T}}$ ventilation increased the inflammatory response as shown by increases in IL-6, IL- $1 \beta$, and CXCL- 1 content in BALF and number of inflammatory cells in the lung. In addition, high $\mathrm{V}_{\mathrm{T}}$ altered the dynamic compliance due to hyperinflation as shown previously (7). The difference between set and inspired $\mathrm{V}_{\mathrm{T}}$ suggests tube leakage and/or expansion of tubing of the ventilator circuit which may influence the compliance measurement. No clinical signs for pneumothorax were observed. Thus, low- $\mathrm{V}_{\mathrm{T}}$ ventilation with room air for $8 \mathrm{~h}$ results in a mild inflammatory response in the neonatal lung that is not overtly injurious (no change in dynamic compliance but an increase in the amount of protein in BALF). However, it is plausible that longer durations of low- $\mathrm{V}_{\mathrm{T}}$ ventilation increase the levels of pro-inflammatory cytokines sufficiently to cause lung injury. Although the low- $\mathrm{V}_{\mathrm{T}}$ ventilation strategy $(\sim 3.5 \mathrm{~mL} / \mathrm{kg})$ cannot be compared with clinical 
applied HFOV $\left(\mathrm{V}_{\mathrm{T}} 0.5-2.0 \mathrm{~mL} / \mathrm{kg}\right)$, our finding of an inflammatory response may explain why randomized controlled trials did not show any beneficial effect of protective HFOV in preventing BPD in premature infants. This explanation is supported by several studies in which MV elevates pulmonary cytokines without cellular injury (19-21).

LPS triggers a network of inflammatory responses by activation of macrophages and recruitment of neutrophils, which was also observed in this study. Activated macrophages release different proinflammatory cytokines and neutrophil activation causes the production of oxygen radicals and the release of granular enzymes, which are associated with injurious processes in the lung $(10,22,23)$. Especially, CXC chemokines and IL-8 activate and attract neutrophils into interstitial and alveolar spaces of the lung. Blocking neutrophils by blocking the CXCL-2 receptor led to increased alveolar formation and CXCL-2 null mice exhibited less ventilatorinduced lung injury $(10,24)$. Several studies have shown that high- $\mathrm{V}_{\mathrm{T}}$ ventilation combined with another lung injury amplifies the inflammatory response in adult lungs $(25,26)$. A significant increase of CXCL-2 was measured in BALF of adult rats when high- $\mathrm{V}_{\mathrm{T}}$ ventilation $(40 \mathrm{~mL} / \mathrm{kg})$ was superimposed on a systemic inflammatory process (25). Ventilation of adult mice with smaller $\mathrm{V}_{\mathrm{T}}(6 \mathrm{~mL} / \mathrm{kg})$ after induction of lung injury with hydrochloric acid showed a significant increase of IL-6 content in lung tissue versus ventilation alone (26). High- $\mathrm{V}_{\mathrm{T}}$ ventilation of neonatal rat lungs superimposed on a systemic inflammation induced by LPS (7) significantly increased IL-6 mRNA expression compared with high- $\mathrm{V}_{\mathrm{T}}$ ventilation alone. In this study, we found an additive effect of 50\% oxygen on $\mathrm{LV}_{\mathrm{T}}$-induced expression of IL-6, in agreement with our previous study using $100 \%$ oxygen and high $\mathrm{V}_{\mathrm{T}}$ (14). Whether the additive effect of oxygen on IL-6 expression is harmful remains a matter of speculation. IL- 6 has long been considered a pro-inflammatory cytokine but adult transgenic mice that over-express IL-6 are more resistant to oxidative injury (27), whereas newborn IL-6 transgenic mice demonstrated more cell death after $100 \%$ oxygen exposure (28). These data suggest that high levels of IL- 6 in the lung may actually be beneficial in adult mice but harmful in newborn mice. Surprisingly, we found that preexposure to LPS did not further increase IL-6 message levels when compared with $L V_{T}$ ventilation alone. In contrast, the combination of low- $V_{T}$ ventilation with 50\% oxygen after exposure to LPS further amplified the mRNA expression of IL-6. The increased expression of IL-6 mRNA after $\mathrm{LV}_{\mathrm{T}}$ ventilation with and without oxygen, which was reflected in increased concentrations of this cytokine in BALF. LPS preexposure did not further increase BALF levels of IL-6. $\mathrm{LV}_{\mathrm{T}}$ ventilation with $50 \%$ oxygen also increased the mRNA expression of CXCL-2 versus ventilation alone. Pretreatment with LPS had no significant additive effect on CXCL-2 expression, in contrast to our previous findings with high- $\mathrm{V}_{\mathrm{T}}$ ventilation (7). No correlation between CXCL-2 mRNA expression and CXCL-1 protein content in BALF was observed, suggesting that CXCL-2 and CXCL-1 are not interchangeable. Together, these findings suggest that low $\mathrm{V}_{\mathrm{T}}$ ventilation avoids the synergistic effect of ventilation and systemic inflammation on cytokine/chemokine expression seen with high $\mathrm{V}_{\mathrm{T}}(7,10)$. In contrast, oxygen has an additive effect on ventilation-induced cytokine/chemokine expression which is $\mathrm{V}_{\mathrm{T}}$ independent. Interestingly, upregulated CXCL-2 message was reduced to NV control levels when LPS-treated newborn rats were ventilated with $50 \%$ oxygen. This complex immunomodulatory regulation of CXCL-2 and IL-6 resembles that seen in LPS tolerant mice (29). Pulmonary IL-6 levels were significantly increased in the tolerant mice on further LPS challenge, whereas CXCL-2 levels were significantly reduced. However, it is unlikely that a single exposure to LPS induced tolerance in our model.

We conclude that even low tidal volume ventilation can mount an inflammatory response in the newborn rat, which is amplified by a clinically relevant concentration of inspired oxygen.

\section{REFERENCES}

1. Speer CP 2006 Inflammation and bronchopulmonary dysplasia: a continuing story. Semin Fetal Neonatal Med 11:354-362

2. Ghezzi F, Gomez R, Romero R, Yoon BH, Edwin SS, David C, Janisse J, Mazor M 1998 Elevated interleukin-8 concentrations in amniotic fluid of mothers whose neonates subsequently develop bronchopulmonary dysplasia. Eur J Obstet Gynecol Reprod Biol 78:5-10

3. Groneck P, Gotze-Speer B, Oppermann M, Eiffert H, Speer CP 1994 Association of pulmonary inflammation and increased microvascular permeability during the development of bronchopulmonary dysplasia: a sequential analysis of inflammatory mediators in respiratory fluids of high-risk preterm neonates. Pediatrics 93:712-718

4. Yoder BA, Siler-Khodr T, Winter VT, Coalson JJ 2000 High-frequency oscillatory ventilation: effects on lung function, mechanics, and airway cytokines in the immature baboon model for neonatal chronic lung disease. Am J Respir Crit Care Med 162:1867-1876

5. Imai Y, Nakagawa S, Ito Y, Kawano T, Slutsky AS, Miyasaka K 2001 Comparison of lung protection strategies using conventional and high-frequency oscillatory ventilation. J Appl Physiol 91:1836-1844

6. Altemeier WA, Matute-Bello G, Frevert CW, Kawata Y, Kajikawa O, Martin TR, Glenny RW 2004 Mechanical ventilation with moderate tidal volumes synergistically increases lung cytokine response to systemic endotoxin. Am J Physiol Lung Cell Mol Physiol 287:L533-L542

7. Roth-Kleiner M, Ridsdale R, Cao L, Kuliszewski M, Tseu I, McKerlie C, Post M 2007 Lipopolysaccharide exposure modifies high tidal volume ventilation-induced proinflammatory mediator expression in newborn rat lungs. Pediatr Res 61:191-196

8. Bonikos DS, Bensch KG, Northway WH Jr, Edwards DK 1976 Bronchopulmonary dysplasia: the pulmonary pathologic sequel of necrotizing bronchiolitis and pulmonary fibrosis. Hum Pathol 7:643-666

9. Jankov RP, Johnstone L, Luo X, Robinson BH, Tanswell AK 2003 Macrophages as a major source of oxygen radicals in the hyperoxic newborn rat lung. Free Radic Biol Med 35:200-209

10. Yi M, Jankov RP, Belcastro R, Humes D, Copland I, Shek S, Sweezey NB, Post M, Albertine KH, Auten RL, Tanswell AK 2004 Opposing effects of $60 \%$ oxygen and neutrophil influx on alveologenesis in the neonatal rat. Am J Respir Crit Care Med 170:1188-1196

11. Davis JM, Dickerson B, Metlay L, Penney DP 1991 Differential effects of oxygen and barotrauma on lung injury in the neonatal piglet. Pediatr Pulmonol 10:157-163

12. Delemos RA, Coalson JJ, Gerstmann DR, Kuehl TJ, Null DM Jr 1987 Oxygen toxicity in the premature baboon with hyaline membrane disease. Am Rev Respir Dis 136:677-682

13. Copland IB, Kavanagh BP, Engelberts D, McKerlie C, Belik J, Post M 2003 Early changes in lung gene expression due to high tidal volume. Am J Respir Crit Care Med 168:1051-1059

14. Copland IB, Martinez F, Kavanagh BP, Engelberts D, McKerlie C, Belik J, Post M 2004 High tidal volume ventilation causes different inflammatory responses in newborn versus adult lung. Am J Respir Crit Care Med 169:739-748

15. Liu Q, Lowry TF, Wong-Riley MT 2006 Postnatal changes in ventilation during normoxia and acute hypoxia in the rat: implication for a sensitive period. J Physiol 577:957-970

16. Capoluongo E, Vento G, Santonocito C, Matassa PG, Vaccarella C, Giardina B, Romagnoli C, Zuppi C, Ameglio F 2005 Comparison of serum levels of seven cytokines in premature newborns undergoing different ventilatory procedures: high frequency oscillatory ventilation or synchronized intermittent mandatory ventilation. Eur Cytokine Netw 16:199-205

17. Vento G, Matassa PG, Ameglio F, Capoluongo E, Zecca E, Tortorolo L, Martelli M, Romagnoli C 2005 HFOV in premature neonates: effects on pulmonary mechanics and epithelial lining fluid cytokines. A randomized controlled trial. Intensive Care Med 31:463-470 
18. Thome U, Gotze-Speer B, Speer CP, Pohlandt F 1998 Comparison of pulmonary inflammatory mediators in preterm infants treated with intermittent positive pressure ventilation or high frequency oscillatory ventilation. Pediatr Res 44:330-337

19. Vaneker M, Halbertsma FJ, van Egmond J, Netea MG, Dijkman HB, Snijdelaar DG, Joosten LA, van der Hoeven JG, Scheffer GJ 2007 Mechanical ventilation in healthy mice induces reversible pulmonary and systemic cytokine elevation with preserved alveolar integrity: an in vivo model using clinical relevant ventilation settings. Anesthesiology 107:419-426

20. Yamamoto H, Teramoto H, Uetani K, Igawa K, Shimizu E 2002 Cyclic stretch upregulates interleukin- 8 and transforming growth factor-beta1 production through a protein kinase C-dependent pathway in alveolar epithelial cells. Respirology 7:103109

21. Vlahakis NE, Schroeder MA, Limper AH, Hubmayr RD 1999 Stretch induces cytokine release by alveolar epithelial cells in vitro. Am J Physiol 277:L167-L173

22. Sibille Y, Reynolds HY 1990 Macrophages and polymorphonuclear neutrophils in lung defense and injury. Am Rev Respir Dis 141:471-501

23. Jobe AH, Ikegami M 1998 Mechanisms initiating lung injury in the preterm. Early Hum Dev 53:81-94
24. Belperio JA, Keane MP, Burdick MD, Londhe V, Xue YY, Li K, Phillips RJ, Strieter RM 2002 Critical role for CXCR2 and CXCR2 ligands during the pathogenesis of ventilator-induced lung injury. J Clin Invest 110:1703-1716

25. Tremblay L, Valenza F, Ribeiro SP, Li J, Slutsky AS 1997 Injurious ventilatory strategies increase cytokines and c-fos m-RNA expression in an isolated rat lung model. J Clin Invest 99:944-952

26. Gurkan OU, O’Donnell C, Brower R, Ruckdeschel E, Becker PM 2003 Differential effects of mechanical ventilatory strategy on lung injury and systemic organ inflammation in mice. Am J Physiol Lung Cell Mol Physiol 285:L710-L718

27. Ward NS, Waxman AB, Homer RJ, Mantell LL, Einarsson O, Du Y, Elias JA 2000 Interleukin-6-induced protection in hyperoxic acute lung injury. Am J Respir Cell Mol Biol 22:535-542

28. Choo-Wing R, Nedrelow JH, Homer RJ, Elias JA, Bhandari V 2007 Developmental differences in the responses of IL-6 and IL-13 transgenic mice exposed to hyperoxia. Am J Physiol Lung Cell Mol Physiol 293:L142-L150

29. Natarajan S, Kim J, Remick DG 2010 Chronic pulmonary LPS tolerance induces selective immunosuppression while maintaining the neutrophilic response. Shock 33:162-169 